\title{
African Migrant Christianities - Delocalization or Relocalization of Identities?
}

\author{
Stian Sørlie Eriksen, Tomas Sundnes Drønen and Ingrid Løland
}

\section{1 \\ Introduction}

African migrant Christianity is a field that has been attracting increased academic interest in recent decades. Numerous studies within anthropology and theology have discussed the topic in general and activities connected with it in different countries in particular. In addition, the theme has been studied as a transnational field where the relationship between the soil of the ancestors and the new homeland has been brought to the fore. This chapter highlights two particular aspects of epistemological and ontological interest in order to address the question of how anthropology and theology can come into dialogue: firstly, through analysis of how technology influences human behavior, permits simultaneity, and affects Christian discursive practices in transnational and transcultural relations; secondly, by looking at how migration and the new media affect identity construction for the individual believer.

The chapter will start by highlighting some of the globalizing processes that have influenced the development of various African Christianities and, in particular, the activities of the Nigerian-based Redeemed Christian Church of God (RCCG) in Norway. Of special interest is how technological media and new forms of communication - in particular through the Internet and social media - generate simultaneity in religious practices and facilitate the development of congregations across long distances. The second section of the chapter deals with the relationship between migration, identity construction, and religion, focusing in particular on theories of identity construction linked to religious practices in diaspora churches.

Towards the end of the chapter recent developments among African transnational churches are discussed within the framework of technology and forms of identity-making. How do technological innovations influence the individual, and how do questions of technology and migration affect theology, understood as religious discursive practices? Does the intensified use of the Internet and social media favor theories of delocalized identities, or could it be 
argued that it leads to a relocalization of identities through transnational Pentecostal networks?

\section{$2 \quad$ African Christianities and the Wider World}

The extensive production of scholarly works on globalization and the growth of Pentecostalism in sub-Saharan Africa has raised many interesting questions and provided several good answers. One central issue which has been brought to the fore is what we could call the relationship between Africa and the wider world, a theme that has engaged both anthropologists and theologians who have discussed terms such as identity, modernity, globalization, and the media. ${ }^{1}$ It has been established as an undeniable fact that the growth of PentecostalCharismatic Christianity in Africa has not happened in a vacuum, and that the development is the result of a multiplicity of social, economic, and technological changes which have the common denominator of moving different social worlds closer together due to increased connectivity. Often referred to as various processes of globalization, this connectivity can be approached from different perspectives. Several recent debates on globalization discuss whether current developments are the results of long-term historical processes, and we might ask whether studies of the contemporary Pentecostal tide ${ }^{2}$ in Africa should have Jerusalem, the Berlin conference, or Azusa Street as its starting point - that is, if we approach globalization from the perspective of la longue durée. Alternatively, we could follow scholars who see the Pentecostal movement in Africa as the extended arm of current North American TV evangelism, ${ }^{3}$ and/or study religion and technological developments through the distribution of literature, cassettes, videos, CDs, and radio and TV transmissions. ${ }^{4}$

1 Among others Ruth Marshall-Fratani, "Mediating the Global and Local in Nigerian Pentecostalism," in Between Babel and Pentecost. Transnational Pentecostalism in Africa and Latin America, eds. André Corten and Ruth Marshall-Fratani (Bloomington: Indiana University Press, 2001); Paul Gifford, Ghana's New Christianity: Pentecostalism in a Globalising African Economy (London: Hurst \& Company, 2004); Birgit Meyer, "Christianity in Africa: From Independent to Pentecostal-Charismatic Churches," Annual Review of Anthropology 33 (2004); Joel Robbins, "The Globalization of Pentecostal and Charismatic Christianity," Annual Review of Anthropology 33 (2004); Tomas Sundnes Drønen, Pentecostalism, Globalisation, and Islam in Northern Cameroon. Megachurches in the Making? (Leiden: Brill, 2013).

2 Ogbu Kalu, African Pentecostalism: an introduction (Oxford: Oxford University Press, 2008).

3 Gifford, Ghana's New Christianity.

4 Rosalind I.J. Hackett, "Charismatic/Pentecostal Appropriation of Media Technologies in Nigeria and Ghana," Journal of Religion in Africa XXVIII, no. 3 (1998); Marshall-Fratani, "Mediating the Global and Local"; J. Kwabena Asamoah-Gyadu, "Anointing Through the Screen: 
Others emphasize that African Pentecostalism primarily emerges out of African spirituality and the African Initiated Churches (AICs), often predating Pentecostal churches in Africa. ${ }^{5}$ It is also possible to hold a more convincing view that African Pentecostalism can be seen as a result of a combination of all these influences which have manifested themselves differently at different times and in different contexts. Regardless of whether our approach is that of slow or rapid globalization, ${ }^{6}$ processes connected with it have made Pentecostalism accessible to new audiences all over Africa.

In order to understand the development of Christianities in Africa in general, and that of Pentecostalism in particular, it is obvious that all the abovementioned approaches to religious change have to be taken into consideration. Equally important, however, is the issue of migration, one aspect of the social and economic change that has transformed Africa (and consequently) influenced individual ideas of identity. The issue of Christian African diaspora communities, especially in Europe and in North America, has recently gained considerable momentum in academic circles. From Gerrie ter Haar's pioneering work, ${ }^{7}$ through publications from scholars such as Peggy Levitt, Ogbu Kalu, Afe Adogame, and Richard Burgess, ${ }^{8}$ detailed descriptions of diaspora theology and discursive practices are now available for scholars and students of African Christianity.

\section{3}

\section{The Redeemed Christian Church of God in Norway}

As an illustrative example, in this chapter we briefly present the transnational activities of the RCCG in Norway and globally. Having been termed the arrowhead of Nigerian Pentecostalism, the RCCG has been among the largest and

Neo-Pentecostalism and Televised Christianity in Ghana," Studies in World Christianity 11, no. 1 (2005); Harri Englund, Christianity and Public Culture in Africa (Ohio: Ohio University Press, 2011).

5 Kalu, African Pentecostalism, 66-68.

6 Drønen, Pentecostalism, Globalisation, and Islam.

7 Gerrie ter Haar, Halfway to Paradise. African Christians in Europe (Cardiff: Cardiff Academic Press, 1998).

8 Peggy Levitt, "You Know Abraham Really was the First Migrant': Transnational Migration and Religion," International Migration Review 37, no. 3 (2003); Ogbu Kalu, "African Pentecostalism in Diaspora," PentecoStudies 9, no. 1 (2010); Afe Adogame, "Transnational Migration and Pentecostalism in Europe," PentecoStudies 9, no. 1 (2010); Afe Adogame, The African Christian Diaspora (London: Bloomsbury, 2013); Richard Burgess, Kim Knibbe, and Anna Quaas, "Nigerian-Initiated Pentecostal Churches as a Social Force in Europe: The Case of the Redeemed Christian Church of God," PentecoStudies 9, no. 1 (2010). 
fastest growing Pentecostal groups in Nigeria, with a religious and societal influence extending far beyond its own denomination. ${ }^{9}$ Through its structure and mission strategies and by following Nigerians' migration routes and destinations, the RCCG website reports that the church has gained global presence in more than 178 nations. ${ }^{10}$ The largest communities are to be found in the United Kingdom and the United States, but even in the Middle East and Asia there are now RCCG communities. This has made it a church that is frequently referenced in large numbers of studies in a range of disciplines, and it is particularly identified with its international general overseer, Enoch Adejare Adeboye." In the Nordic countries, RCCG churches are part of the RCCG Europe Mainland Region 3, headquartered in Sweden but currently led by Pastor Sola David Oludoyi who resides in the UK. ${ }^{12}$

In Norway, the RCCG was established in 2000 by Nigerian Pastor Duke Ajieh who had formerly worked as an RCCG-trained missionary to Port Hartcourt in Nigeria before coming to Oslo. ${ }^{13}$ Until his death in 2017, pastor Ajieh was the national coordinator for eight congregations in seven Norwegian cities, amounting to between $700-800$ members in total..$^{14}$ Parish membership, however, varies, often fluctuating due to migratory issues. Although the size of congregations and numbers of members are relatively small, the RCCG actively seeks to expand into new areas and regions. Some of the more recent congregations were established on the west coast of Norway in Stavanger, Bergen, and Haugesund, emerging in the wake of the Norwegian oil industry when Nigerian petroleum engineers came to the region in order to work for international oil companies or study petroleum engineering at local universities. In Norway, RCCG churches do not only attract members with RCCG background, but

9 Olufunke Adeboye, “Arrowhead' of Nigerian Pentecostalism: The Redeemed Christian Church of God 1952-2005," Pneuma 29, no. 1 (2007); Asonzeh Ukah, A New Paradigm of Pentecostal Power: A Study of the Redeemed Christian Church of God in Nigeria (Trenton: Africa World Press, 2008).

10 http://rccg.org, accessed December 14, 2018.

11 Due to recent legal changes governing, among other institutions, religious bodies and churches in Nigeria, Enoch Adeboye stepped down as general overseer of the RCCG Nigeria, but remains the RCCG's spiritual leader and general overseer of the RCCG worldwide. The legal decision was controversial and much discussed in Nigeria. The RCCG is also known for its Redemption Camp, which in essence is an RCCG "city" in the making. The RCCG is currently constructing what is known to be the largest church/auditorium in the world in order to accommodate large crowds at conventions and spiritual rallies.

“RCCG Europe Mainland," http://www.rccgmainlandeurope.org/eastprovince.asp, accessed January 20, 2017.

13 Interview with Duke Aijeh, Oslo, February 2, 2014.

14 The national coordinator of RCCG Norway is today Florence Ajieh, the widow of pastor Duke Ajieh. 
Christians from a variety of nations with equally varied congregational experiences.

In order to understand how the RCCG operates on the local level it is important to understand the regional and global organization of the church. The late RCCG national coordinator, Duke Ajieh, commented on the importance of the RCCG structure for the church in Norway in the following way:

The structure of Redeemed is so fantastic, you know. I'm here, I'm not standing alone. Even if this is the national headquarters in Norway. But yet, I am still under authority of the region.... We have what we call Europe Mainland Mission within the Redeemed Christian Church of God with the headquarters, the regional headquarters, in Amsterdam in Holland. So I am responsible for them. I send my reports to the regional office. The regional office in turn sends this report to the national headquarters in Lagos.... So Pastor Adeboye is aware of what is happening ... here. ${ }^{15}$

Hermeneutically and contextually speaking, these perspectives help us understand how the RCCG contributes to identity formation among diaspora Christians in Norway. For example, by identifying with the RCCG, one identifies not only with a growing and global movement, but also with the societal and spiritual esteem associated with Enoch Adeboye and the RCCG, as well as with the projection of spiritual power seen at RCCG spiritual rallies. For example, as displayed in a film and drama presentation called The Latter Rain (which was also the theme of the event) at the Festival of Life in Stockholm in April 2016, the emergence of the RCCG under the leadership of Adeboye was depicted as an "end time" move by God. In the presentation, the emergence of the RCCG was compared to the movements that followed historical figures such as Martin Luther and well-known evangelists and Pentecostal leaders in the 19th and 2oth centuries such as John Alexander Dowie, Aimee Semple McPherson, and Kathryn Kuhlman. In other words, by being part of the RCCG, one is part of what God is doing today. ${ }^{16}$

Recent studies of the neo-Pentecostal movement in Africa show that religious culture, spiritual worldview, and individual identity is rapidly changing,

15 Ibid. In addition, our analyses are based on previous knowledge as well as ethnographic field studies and participant observation of the RCCG in Norway over the course of about two years, from the fall of 2014 through the summer of 2016.

16 See https://www.youtube.com/watch?v=bsMgeHJGSZw, about 01:58-02:20, accessed October 3, 2016. 
and that researchers need to develop a "conceptual and methodological toolbox that enables meaningful reflection on the contextualization processes of the Christian faith." ${ }^{17}$ One way to take these challenges seriously is to look further into how individual African Christians and congregations are entering new spaces where information is transmitted. It is a long path, epistemologically and ontologically speaking, from the meetings in the village church, where the closest contact with the outside world was an evangelist who had once met a missionary at a regional meeting, to receiving daily updates on Facebook from your sister who is member of an African migrant church in the Norwegian oil capital, Stavanger. Let us therefore take a further look into how technology has affected the development of African Christianity.

One of the pioneers in the study of media and African Pentecostal churches, Rosalind Hackett, wrote the following in 1998:

I argue further that these developments result in the transformation of the religious landscape in at least two ways: one, they are facilitating transnational and homogenizing cultural flows, and two, they are taking the connections between these movements and the networks they create to new, global levels. ${ }^{18}$

By relating her findings from media practices in Pentecostal churches in Ghana to Roland Robertson's ${ }^{19}$ focus on globalization as a dialectic between homogenizing and heterogenizing forces, ${ }^{20}$ Hackett draws attention to a central issue regarding the changing role of African Pentecostal churches, particularly in the diaspora. The intensified use of media, and especially the Internet, has made religious practices compatible with a modern technological lifestyle that was previously a marker of difference between developed and less developed societies. For members of the RCCG congregation in Stavanger, this means that they can use technology as a means to connect themselves to virtual

\footnotetext{
17 Martha Frederiks, "Religion, Migration and Identity. A Conceptual and Theoretical Exploration," Mission Studies 32, no. 2 (2015), 198.

18 Hackett, "Charismatic/Pentecostal Appropriation," 258.

19 Roland Robertson, "Glocalization: Time-Space and Homogeneity-Heterogenity," in Global Modernities, eds. Mike Featherstone, Scott Lash and Roland Robertson (London: Sage, 1995).

$20 \quad$ Hackett, "Charismatic/Pentecostal Appropriation," 271.
} 
conversations across long distances. The Twitter and Facebook accounts of the RCC G Norwegian headquarters reveal a steady flow of inspirational tweets and posts from the Nigeria-based pastor, Enoch Adeboye, in sync with advertisements and information from regional offices or individual local congregations in Norway and Europe. This adds to a virtual global, regional, and national RCCG community to which one is connected. The members of the RCCG congregation in Stavanger can also use the technological skills they acquire through their jobs in the oil business-related companies with whom they work, both in their private religious practices, and in order to help develop the media strategy of the RCCG as a global network.

Another example of simultaneity and connectivity is the use of internet radio. RCCG Radio (www.myrccgradio.com) is one of several RCCG internet radio stations that broadcast nonstop RCCG-related news, publicity for upcoming RCCG events, inspirational messages from Enoch Adeboye and others, in addition to a wide selection of Western as well as African gospel music. The radio broadcasts are not limited to religious content but also include sections on news, sports, business, finance, and politics, as well as nutrition and health tips. The interconnectedness of these stations with various social media platforms provides multiple virtual venues through which RCCG members and others can stay connected (which is one of the radio station's slogans) to home base as well as to the larger global RCCG community. As expressed by one of our Nigerian informants living in Norway:

Thanks to the technology available, you can tune into whichever message you want to hear. You have them on YouTube, you have their website, you have the podcast, so I don't feel... even if I'm lacking something here, I can always get it somehow. So I don't really have to travel or go somewhere, no, because I have a way of getting it. ... So I don't feel that gap anymore... ${ }^{21}$

When members and other social media followers of RCCG's congregation in Stavanger are reminded to read Adeboye's Open Heavens devotional entry for the day, they do this in relative synchrony with members and followers all over the world. This way they can virtually take a place around Daddy G.O.'s (Adeboye's nickname) breakfast table, where he shares his spiritual wisdom and

21 Interview, leader in an RCCG congregation in Norway (name and place made anonymous), December 2015 . 
admonition for the day. ${ }^{22}$ When the monthly Holy Ghost Services, or major conventions in Nigeria, are broadcasted live on RCCG's YouTube channel, listeners and viewers have the opportunity to interact in simultaneous real time, for example, through liking or responding to the flow of tweets from the sermon.

Such virtual activities, which are sponsored by all the important African Pentecostal churches, ${ }^{23}$ serve many purposes. First, they promote the notion of simultaneity, ${ }^{24}$ the fact that members of diaspora communities are engaged in the same daily activities in both place of origin and destination country. Through the church websites and frequent updates on Twitter, Facebook, and Instagram, the individual believer is informed of news regarding the home congregation and at the same time confirmed as an active and full member of the expanding policy of the church by being at the frontier of the missionary ideology of the Pentecostal churches. It is, for example, possible to follow Nigerian pastors such as Enoch Adeboye, David Oyedepo, and T.B. Joshua as they proceed from place to place, whether they are being received at the United Nations, preaching to their congregations in London, or crusading in South America. Second, they provide the individual with the opportunity to practice a personal religious life according to the norms and moral codes of the mother church through virtual praying rooms and access to podcasts of services and preaching conducted by the head pastor. With the RCCG it is also possible to link the e-Sunday School podcast directly to your mobile phone, so that you receive the weekly updates. ${ }^{25}$ Not least, major conventions and programs are broadcasted, streamed, and viewed live globally. Third, these virtual activities strengthen the economy of the church through the online donation links which underscore the simultaneity aspect; donations help strengthen the work of the church both at home and in the host country, enabling the church to expand and fulfill its missionary ambitions. Fourth, this kind of "online

22 This was the way Adeboye described the origin and purpose of the Open Heavens devotional in one of the video messages at Open Heavens International Center at Redemption Camp, http://ohic.org, accessed October 1, 2016.

23 J. Kwabena Asamoah-Gyadu, ““'Get on the Internet!” Says the LORD': Religion, Cyberspace and Christianity in Contemporary Africa," Studies in World Christianity 13, no. 3 (2007); Rosalind I.J. Hackett, "The New Virtual (Inter)Face of African Pentecostalism," Society 46 (2009).

24 Peggy Levitt and Nina Glick Schiller. "Conceptualizing Simultaneity: A Transnational Social Field Perspective on Society," International Migration Review 38, no. 3 (2004).

25 This service is available in different versions for Apple, Android, Blackberry, Windows and Nokia devices. 
religion" ${ }^{26}$ promotes what Ogbu Kalu calls a "Big man with a big God", ${ }^{27}$ through websites with a strong focus on the leader of the church. Numerous photos and videos of the big pastors convey an image of spiritual and material success, connecting the individual member of the church more closely to the leader and creating individual loyalty to a strong organization with a clearly defined leadership and specific goals in mind. In RCCG congregations worldwide, ${ }^{28}$ it is common to show a video containing a recent message from Daddy G.O. on a big screen during the service, especially in conjunction with major events in the church.

Relating this to connectivity and media technology, RCCG theology and beliefs seem to indicate that spiritual power can also flow in virtual space, and during streamed services those watching are often mentioned by Adeboye or other speakers, encouraging them to respond to the message in the same way as those physically present. During the previously mentioned Festival of Life in Stockholm, attendees were encouraged with the following words:

Presently the program is live on YouTube ... [applause]. And we'd kind of advise you, if you can tweet, sms, WhatsApp, or get somebody online to join, then God will bless them abundantly in Jesus' name. ... Amen. ${ }^{29}$

It seems as if online presence can function as an extension of, or as a good alternative to, physical presence at the service. Similarly, anointing oil or prayer cloths, first prayed over by Adeboye or others to whom he has delegated authority, can be distributed to churches in various countries, and if they are not available, those watching may use their own, perhaps having them prayed over during the online broadcast. Returning to the question of identity, it seems from the local perspectives we have observed that these practices contribute to a sense of proximity and connection to something larger. From listening to conversations about Adeboye in RCCG meetings in Norway, Sweden, and the Netherlands, one may at least conclude that the practices represent images of spiritual strength which connect the individual to something bigger than the

26 See Knut Lundby, "Patterns of Belonging in Online/Offline Interfaces of Religion," Information, Communication \& Society 14, no. 8 (2011) for a discussion about the difference in meaning concerning the terms "religion online" and "online religion."

27 Kalu, African Pentecostalism, 113.

28 The RCCG website claims that the church is present in 180 countries worldwide, and that the church has more than 700 parishes in the UK alone, www.rccguk.church/our-history/, accessed August 4, 2016.

29 See https://www.youtube.com/watch?v=bsMgeHJGSZw, about 01:55-01:56, accessed October 1, 2016. 
local, and yet which also inspire continued participation in church activities locally.

The notion of simultaneity does not only have anthropological implications, it also has theological consequences. Dealing with time, Pentecostals understand God to act in the now. By capturing this appointed (and anointed) time through streaming or recording a broadcast, believers can disconnect the moment from both geographical place and chronological time so that one can feel the presence of God while watching a recording or during reruns of audio or video broadcasts anywhere in the world. Since a key issue is the individual's response to God, prayers can also be carried out while following the sermons online, even after the factual event took place. In one sense, this ability to connect in virtual space enables individuals to link to church networks back home or anywhere in the world. On the other hand, however, it may also involve a sense of disconnection from geographical and physical space or even local or specific churches in terms of loyalty. Linking back to one of the previously quoted informants, the individual can today choose his or her sources of information in a way that was not possible only a decade ago, empowering the religious self to form his or her religious environment. At the same time, however, disconnection and individualization may affect the nature and the meaning of religious practice for the individual. From this and other observations, we have the impression that following online events provides connectivity, identity, and participation, yet perhaps in a different way than when physically present. Simultaneity, therefore, also becomes a flexible notion, meaning that people can follow and respond in relative and proximate but not necessarily absolute simultaneity.

Birgit Meyer and Annelies Moors highlight another fundamental question related to the role of media in religious communities in their book Religion, Media and the Public Sphere. ${ }^{30}$ When dealing with questions of migration, simultaneity and identity construction, the role that religion plays in the public sphere is a highly relevant issue. The fact that the African churches originate in societies where religion is an important part of everyday life, both in state affairs and in civil society, might create tension when they establish their missionary activities in societies where, for several decades, religion has primarily

$30 \quad$ Birgit Meyer and Annelies Moors, Religion, Media, and the Public Sphere (Bloomington: Indiana University Press, 2005). 
been associated with the individual and the private sphere. It is here noticeable that a double development within the migrant churches has consequences for the wider society.

First of all, the extensive focus on using the Internet as the platform of communication between the major hubs of the home church and the diaspora is a public event. Anyone can visit the website of the church, and anyone can see the videos from services and conventions, all available through YouTube and other public channels. Secondly, the fact that these churches are both expanding and also conducting public events is attracting the attention of the secular media. When the RCCG convention in Stockholm in 2016 drew 3,00o participants to the Globe, it was a matter of public interest, and when the then UK Prime Minister, David Cameron, visited the RCCG's Festival of Life in London during his election campaign in 2015, it was reported by several large UK news channels. In addition, participants from Norway and other parts of the world shared the event's internet links or live moments from their smartphones onto Facebook and other social media, making it available in the now to far more than the 40,00o people who were physically present at the London venue. Thus, being part of significant social movements influences the way individuals see themselves as part of the larger society. Our contention is that the way migrant churches increasingly inhabit public space influences identity construction among the migrant population. Finding a place in a new society may be a challenging affair for migrants, highlighting the need for many to seek spaces where they can feel at ease and be considered as real and contributing members. For example, in RCCG churches in Norway, we encountered members from various kinds of church backgrounds, many of whom expressed a preference for joining the RCCG congregation, somewhere they felt at home socially, culturally, and spiritually. The church provided a recognizable spiritual and social environment, not least in light of being a foreigner in Norway. In contrast, it was not uncommon to hear comments that it had been difficult for many to find similar connections in the Norwegian churches they had attended. Amélé Ekué ${ }^{31}$ claims that migrant congregations often play this role of a safe haven, further discussing how these religious communities can play a vital role in the individual life situation. This brings our discussion closer to how technology and simultaneity influence the migratory situation, primarily through questions related to identity.

$31 \quad$ Amélé Adamavi-Aho Ekué, "Migrant Christians: Believing Wanderers between Cultures and Nations," The Ecumenical Review 61, no. 4 (2009). 
Studies of migration have for some time been in dialogue with anthropology and the philosophy of science in order to discuss identity construction, both as an ontological and as an epistemological field of interest. Whether addressing what constitutes human identity or methodically figuring out how to discuss these findings, no single authoritative answer has emerged from the abundance of scientific inquiries. Identity flux between individual and collective self-understanding forming a dialectic interplay between self-representation and social categorization. ${ }^{32}$ The understanding of identity as a stable core of the self - "unfolding from beginning to end through all the vicissitudes of history without change" 33 - has been especially prevalent when talking about cultural, ethnic, and religious identities. ${ }^{34}$ Indeed, the human need for security, and reliance upon a lifeline of truth and belonging - especially in times of risks and threats - must be taken seriously in order to understand the role that the new Pentecostal churches play within the development of the African ecclesiological geography, both in Africa and in Europe.

According to Gerd Baumann, however, a narrow focus on "a stable core of the self" falls short of explaining identities as part of the multifaceted and multicultural riddle ${ }^{35}$ pertaining to the globalized world, and several new scientific paradigms have been launched highlighting change, dynamism, contextualization, and social interaction as constitutive elements of identity. The element of change and context, for instance, has been noted by many, among them the sociologist Zygmunt Bauman. ${ }^{36}$ His point is that all axioms, convictions, and takenfor-granted assumptions, the whole idea about permanency in life, are illusory and not compatible with a modern understanding of changes in time and space. From the combined fields of theology and psychology F. LeRon Shults

32 Maria Catarina La Barbera, "Identity and Migration: An Introduction," in Identity and Migration in Europe: Multidiciplinary Perspectives, ed. Maria Catarina La Barbera (Cham: Springer International Publishing, 2015); Jeffrey R. Seul, "'Ours is the Way of God': Religion, Identity, and Intergroup Conflict," Journal of Peace Research 36, no. 5 (1999).

33 Stuart Hall, "Introduction: Who Needs Identity?" in Questions of Cultural Identity, eds. Stuart Hall and Paul Du Gay (London: Sage Publications, 1996).

34 Ibid.; Gerd Baumann. The Multicultural Riddle. Rethinking National, Ethnic, and Religious Identities (New York: Routledge, 1999).

35 Baumann, The Multicultural Riddle, 25.

36 Zygmunt Bauman, "Migration and identities in the globalized world," Philosophy and Social Criticism 37, no. 4 (2011): 12. 
and Steven J. Sandage describe identity formation as a relational, interpersonal, and "dialectical" process "between self and non-self" through which "human persons are identified by and identify others." 37 Shults and Sandage quote McAdams' notion that "identity is the storied self" which "gives unity and purpose to life," a claim which is related to his discussion of personality in the context of life stories, spirituality, and religiosity. ${ }^{38}$ From the context of African Pentecostals, an integrative psychological-theological approach to identity fits well with African and Pentecostal life worlds and spiritualities. Having a theological frame for one's life provides tools for interpreting and making sense of daily life as well as addressing existential questions. The RCCG might, for instance, function as a frame for viewing and telling one's own life story.

Going beyond biographical and sociocultural factors, identity, as such, is formed through personal reflection and identification with the other. McAdams' notion ${ }^{39}$ enables us to grasp, in practical terms, the fact that African Christians continue to identify with, and are identified by, active engagement in Pentecostal churches like the RCCG in the diaspora. This helps us realize that the kind of Christian spirituality and organization that the RCCG represents plays an important part in the remaking of Christians' migrant identities. Addressing identity formation among African Christian migrants in Sweden, anthropologist Jan-Åke Alvarsson discusses the characteristics and hybridity of African, emigrant and immigrant identities in these churches, describing how the African churches function as arenas for reformulating life stories and identities. This might, for instance, be concerned with adjusted expectations related to living in Sweden, which had a tendency to change from expectations of winning Europe for the gospel to winning victories in personal lives. ${ }^{40}$ From our interaction with a number of African diaspora church leaders and members, there also seems to be a kind of shared Pentecostal identity with which many identify, relating to the growing global vision and impact of these

37 F. LeRon Shults and Stephen J. Sandage, Transforming Spirituality: Integrating Theology and Psychology (Grand Rapids: Baker Academic, 2006), 82.

38 Ibid., 170.

39 Dan P. McAdams, "What Do We Know When We Know a Person?" Journal of Personality 63 (1995).

40 Jan-Åke Alvarsson, "Afrikanska pentekostaler i Sverige: Kyrkans roll i skapandet av en ny identitet," in Kristne migranter i Norden, eds. Anders Aschim, Olav Hovdelien and Helje Kringlebotn Sødal (Kristiansand: Portal, 2016). For a brief overview account of RCCG in Sweden see also Nils Malmström, "How do we succeed as a church in Sweden? An African response" (paper presented at the World Alliance for Pentecostal Theological Education (WAPTE) Consultation, Stockholm, Sweden, August 24, 2010). 
churches. Being part of the RCCG implies being part of something bigger than oneself and being included in the move and mission of God today. In terms of cultural and religious identity, our findings also coincide with observations made by Gerrie ter Haar and others ${ }^{41}$ that African Christian migrants in diaspora tend to deemphasize Africanness and emphasize shared Christian aspects of their identity. As expressed by one leader in Norway:

We realize that we need to change a lot of the ways we do things in Africa if we really want to reach out to Norwegians because the vision is to reach out to everybody. At the Redeemed Christian Church of God, we are not an African church; by God's grace, we believe we are international. ${ }^{42}$

Another leader expressed this in practical terms:

Yeah, we are getting there and we have a lot of work to do with the choir for we are consciously trying to change the image of the church; it's not a Nigerian church, we want it to be an international church, not Nigerian. So we have a lot of work to do in that area. ${ }^{43}$

In Norway, African constituencies and cultural flavors mark the demographics of most African Pentecostal churches. At the same time, it should not be overlooked that other immigrants and even Norwegians, though perhaps in relatively small numbers, make their way into these churches. One should also not underestimate discourses of becoming more Norwegian or attempts to accommodate more international audiences. In several of the churches we have followed, leaders have often expressed intentions of trying new ways of reaching Norwegians or empowering members to do so by facilitating translation into Norwegian for Norwegian-speaking visitors, for example, or holding Norwegian language training sessions. Consequently, what outsiders may perceive as African, the insider may perceive as less African or even attempting-to-beNorwegian as a result of factors such as printing invitational flyers in Norwegian, singing Norwegian worship songs, or partially speaking Norwegian during a church service. Given the missional focus of the RCCG, missional identity may be part of the identity make-up of Nigerian Christians in Norway, but it cannot

41 Gerrie ter Haar, "African Christians in Europe: A Mission in Reverse," in Changing Relations between Churches in Europe and Africa: The Internationalization of Christianity and Politics in the 2oth Century, eds. Katharina Kunter and Jens Schjørring (Wiesbaden: Harrassowitz Verlag, 2008); Jan-Åke Alvarsson, "Afrikanska pentekostaler i Sverige."

42 Interview, Stavanger, December 2015.

43 Interview, Stavanger, December 2015. 
be taken for granted that it resonates with members to the extent that it does with leaders or official policies. Responding to Martha Frederiks' notion of hybridity of culture and context, it is safer to say that African Christians in Norway hold multiple and hybrid identities. ${ }^{44}$ Identity as such cannot be classified as either-or but rather in-between or in-becoming. Different contexts also demand differences in identity projections. An African pastor's professional LinkedIn profile geared at career building in the marketplace may look quite different from the same person's Facebook profile aimed at his or her family, friends, and extended church community. ${ }^{45}$

In an earlier publication dealing with globalization and African Pentecostal Christianity, ${ }^{46}$ we have drawn attention to André Corten and Ruth MarshallFratani's edited book Between Babel and Pentecost, which gathers together an interesting collection of articles discussing Pentecostal identity construction from different angles. In the introductory chapter they show how global Pentecostalism, through a variety of processes of globalization, has become a bricolage of heterogeneous elements of flow and closure which make up a new vision of the world as a response to different processes and promises of modernity. Globalization is here defined as a mixture of material and symbolic flows which influence institutions and individuals to varying degrees. Corten and Marshall-Fratani underscore the importance of distinguishing between the diffuse nature of global networks that make up a transnational Pentecostal reality on the one hand, and the representation of this transnational community as experienced by the individual Pentecostal believer on the other, but their chapter leaves much to be desired when it comes to indicating how this demarcation line should be drawn. In her following chapter on Nigerian Pentecostalism, Marshall-Fratani seeks to amplify the introductory chapter by explaining how Pentecostalism among young Nigerians tends to create what she calls "transnational imagined communities", communities which connect local Nigerian youth to wider global networks. She readily admits that analyses of these processes are challenging because it is difficult to separate and locate

\footnotetext{
44 Frederiks, Religion, Migration, and Identity.

45 Research among African Pentecostal leaders in Norway has included extensive examination of these in various social media. For the sake of confidentiality, churches and individuals are not identified.

46 Drønen, Pentecostalism, Globalisation, and Islam, 47-48.
} 
the appropriation of these largely symbolic images. ${ }^{47}$ One significant contribution from Marshall-Fratani, however, is her focus on the importance of analyzing the role of global media, a scholarly approach that has been increasingly at the forefront during the last decade:

Such images, ideas and narratives provide 'a series of elements (such as characters, plots and textual forma) out of which scripts can be formed of imagined lives,' scripts which, while interpreted in terms of local everyday experience, are taken from global repertoires, and as such, provide means for imagining communities outside or in defiance of the nationstate's bid to monopolise the resources of community formation. ${ }^{48}$

Regarding the construction of Pentecostal identities and inspired by Arjun Appadurai, Marshall-Fratani asks if the above-mentioned processes create delocalized subjects, or at least subjects whose individual and collective identities are formed through a negotiation between local and global discourses and symbols. ${ }^{49}$ Some of these symbols may include references to success, material blessing, and individual self-worth, perhaps against and in opposition to commonly held circumstantial perceptions about poverty, fate, or destiny. In turn these symbols represent resources which assist individuals as well as communities to arise, change their circumstances, and make a difference.

This discussion about globalization, public religion, and identity in an African setting is also highly relevant for diaspora communities, and here Jesús Martin-Barbero's approach is of interest. He claims that the religious use of the Internet is "an exercise in the re-enchantment of spaces drained of supernatural presence by western secularism." ${ }^{50}$ Mark Cartledge and Andrew Davies also deal with this public presence of religion, ${ }^{51}$ either in physical space or in cyberspace, through their study of the largest megachurch in London, Kingsway International Christian's Centre. Here they draw attention to the innovative ways in which Kingsway uses the Internet in order to be of relevance for their members whose background is largely West African. Members can join the iChurch, post their testimonies online, call Hopeline for prayers, or talk to the

\footnotetext{
47 Marshall-Fratani, "Mediating the Global and Local," 82-83.

48 Ibid., 82.

49 Arjun Appadurai, Modernity at large: cultural dimensions of globalization (Minneapolis: University of Minnesota Press, 1996); Marshall-Fratani, "Mediating the Global and Local," 83 .

50 Cited from Asamoah-Gyadu, "Get on the Internet!," 235.

51 Mark Cartledge and Andrew Davies, "A Megachurch in a Megacity: A Study of Cyberspace Representation," PentecoStudies 13, no. 1 (2014).
} 
pastor on call. There is also an online Single's Ministry responsible for events such as the Single's Christmas Ball. Through this service members from the church can find life partners who share the same values and traditions, thus securing the safety and sameness of cultural identity, while incorporating a redefinition of these values in a different technological and material environment. A community that is partly online and partly offline (partly public and partly private) is created in order to deal with practical needs in all situations in life, an example that resonates with Knut Lundby's research ${ }^{52}$ analyzing religious life between online and offline as a new way to make religion happen. He claims that these kinds of religious practices open up new constellations outside traditional religious communities and, through them, new spaces of belonging are made possible.

This brings us back to the question of identity, and to the resources of identity construction that African migrants receive through the Christian communities in which they participate during their absence from home communities. If globalization creates delocalized subjects through technology at home, one might also ask whether technology can lead to the creation of relocalized identities for migrants uprooted from the localities and resources that have created a sense of belonging, inclusion, and security in their lives. One obvious point of departure is to revisit the question of what creates feelings of belonging to a community. The importance of communal activities is obvious to anyone familiar with African traditions, and the vital role that religious communities play became evident during our observations and interviews in African Pentecostal congregations in Norway, Sweden, and Nigeria. This feeling of belonging, of connecting, and of participating in familiar activities are elements that are brought to the fore when African Christians in Stavanger are asked why they participate in the services organized by various migrant communities. One particular example is how these congregations have managed to become a home away from home for African migrants in the region. In addition to creating environments for familiar forms of worship and preaching, the congregation is a place for communal gatherings and social networking where the members discuss jobs, housing, and access to social welfare benefits. The congregation becomes a resource center where migrants can talk about the challenges connected to building a new life in an unfamiliar cultural environment. Identity is foregrounded in many different ways during these conversations. A primary negative concern which is dwelt upon regards the future of the children who will grow up distanced from the soil of the ancestors, and maybe even from the religion of their parents. On the positive side, this community 
becomes a laboratory for glocalizing events, events that encourage members to engage actively in the ongoing negotiation between old and new cultural and religious contexts.

In an attempt to spread Christian values important in an African setting, the RCC G congregation in Stavanger engages in diaconal work for people with material problems in the region, offers help to refugees, and can periodically be seen at evangelism stands in the city square during weekends. Its members also engage in public events to demonstrate that African Christian migrants can be a resource in society and not only a burden. One example of such an event is their participation in the celebration of the national holiday on 17th May. On a day where schools and civil society organizations join the different parades that are organized, the RCCG is one of very few churches that participate. With African rhythms blending with the beat of a marching band, dancing, and singing, they really stand out in the parade with their blue jackets with "Jesus loves you" written on the back. These people are not examples of delocalized identities; rather, they are individuals trying to redefine cultural values and self-esteem in a new environment. In terms of identity, participation may serve hybrid purposes: hoping to be a good Christian witness by showing the positive and different face of Africans, while at the same time becoming Norwegian by actively taking part in a major Norwegian public event like this. The relocation of identities, as seen in these examples, reminds us to focus on context and culture when discussing migrant religious communities in diverse settings around the world.

Where do migrants find inspiration and courage in this culture-sensitive identity construction project? To give solid answers to that question more detailed research in these communities must be conducted, but let us point to some probable elements. Firstly, participation in services where live messages from the big pastors are transmitted on a regular basis creates an important link to the homeland and to the mother church. This link nurtures the idea of still being included in a large community representing ideas and values familiar to the individual member and providing a connection and a lifeline that creates a reservoir of self-esteem which again helps the individual deal with potential experiences of exclusion and alienation. Secondly, participation in regional conferences helps the individual see that even if their local congregation is small, thousands of migrants in similar situations visit RCCG conventions in Stockholm, Amsterdam, and London. The organization and sacrifices 
connected with travelling together to these events also strengthen the friendship and cultural ties that bind the group together, creating feelings of security and belonging. Finally, the extended use of technology and social media like Facebook, Twitter, and Skype creates a lifeline between home and host country, and between individual migrants in different parts of the world. Stepping inside these virtual communities shows that individuals engage actively in church-related online activities, such as online discussion groups, prayer groups, or evangelism. Here they raise important questions related to a variety of church and life situations, as well as seeking advice for many different practical questions related to the migratory situation and issues of faith and identity. We therefore conclude that technology plays a vital role as a means and an end leading towards what we would call a relocalization of identity through the communities created and maintained by African Christian churches.

However, while globalized technology in one sense brings people together within and outside the diaspora to participate in religious practices in the interface between online and offline religion, which in itself may represent a core of stability, the ways in which religion is practiced are also fundamentally changed by the same technology. In this regard, more research is needed in order to study the ifs, hows and to-what-extents this technological turn changes the core of religion itself and its stability. For example, will a highly marketoriented and always available religion lose its sense of exclusiveness and value when available on the same platforms as casual friendships, advertisements, and self-promotion? Answering these questions, however, lies outside the scope of our current discussion.

\section{$9 \quad$ Concluding Remarks}

The study of African Christianities is an academic field dealing with continuity and change - and it is a study where both anthropological and theological approaches can help us gain more insight into individual identity construction and communal practices. In this chapter, we have seen that Nigerian diaspora communities in Norway play an important role as bridge builders between the cultural identity and religious practices of the home country, and everyday practices in the new homeland. Through new technology, which opens up opportunities for simultaneous global participation, the migrant communities receive a reservoir of inputs that help individuals deal with issues of exclusion and insecurity common in most migratory situations. In other words, technology helps the individual to relocalize issues related to cultural and religious identity construction, bringing forth issues of human agency, change, and 
adaptability, topics that are often neglected in research on migrants. On the other hand, this simultaneity also gives migrants the possibility to interact with the mother congregation, thus also slowly working a change in religious practices on the soil of the ancestors.

\section{References}

Adeboye, Olufunke. "Arrowhead' of Nigerian Pentecostalism: The Redeemed Christian Church of God 1952-2005," Pneuma 29, no. 1 (2007):24-58.

Adogame, Afe. "Transnational Migration and Pentecostalism in Europe." PentecoStudies 9, no. 1 (2010): $5^{6-73}$.

Adogame, Afe. The African Christian Diaspora. London: Bloomsbury, 2013.

Alvarsson, Jan-Åke. "Afrikanska pentekostaler i Sverige: Kyrkans roll i skapandet av en ny identitet." In Kristne migranter i Norden, edited by Anders Aschim, Olav Hovdelien and Helje Kringlebotn Sødal. Kristiansand, Norway: Portal, 2016.

Appadurai, Arjun. Modernity at large: cultural dimensions of globalization. Minneapolis: University of Minnesota Press, 1996.

Asamoah-Gyadu, J. Kwabena. "Anointing Through the Screen: Neo-Pentecostalism and Televised Christianity in Ghana." Studies in World Christianity 11, no. 1 (2005): $9-28$.

Asamoah-Gyadu, J. Kwabena. “'“Get on the Internet!” Says the LORD': Religion, Cyberspace and Christianity in Contemporary Africa." Studies in World Christianity 13, no. 3 (2007): 225-242.

Bauman, Zygmunt. "Migration and identities in the globalized world." Philosophy and Social Criticism 37, no. 4 (2011): 425-435.

Baumann, Gerd. The Multicultural Riddle. Rethinking National, Ethnic, and Religious Identities. New York: Routledge, 1999.

Burgess, Richard, Kim Knibbe, and Anna Quaas. "Nigerian-Initiated Pentecostal Churches as a Social Force in Europe: The Case of the Redeemed Christian Church of God." PentecoStudies 9, no. 1 (2010): 97-121.

Cartledge, Mark and Andrew Davies. "A Megachurch in a Megacity: A Study of Cyberspace Representation." PentecoStudies 13, no. 1 (2014): 58-79.

Drønen, Tomas Sundnes. Pentecostalism, Globalisation, and Islam in Northern Cameroon. Megachurches in the Making? Leiden: Brill, 2013.

Ekué, Amélé Adamavi-Aho. "Migrant Christians: Believing Wanderers between Cultures and Nations." The Ecumenical Review 61, no. 4 (2009): 387-399.

Englund, Harri. Christianity and Public Culture in Africa. Ohio: Ohio University Press, 2011.

Frederiks, Martha. "Religion, Migration and Identity. A Conceptual and Theoretical Exploration." Mission Studies 32, no. 2 (2015): 181-202. 
Gifford, Paul. Ghana's New Christianity: Pentecostalism in a Globalising African Economy. London: Hurst \& Company, 2004.

Hackett, Rosalind I.J. "Charismatic/Pentecostal Appropriation of Media Technologies in Nigeria and Ghana." Journal of Religion in Africa, XXVIII, no. 3 (1998): 258-277.

Hackett, Rosalind I.J. "The New Virtual (Inter)Face of African Pentecostalism." Society 46, no. 6 (2009): 496-503.

Hall, Stuart. "Introduction: Who Needs Identity?" In Questions of Cultural Identity, edited by Stuart Hall and Paul du Gay. London: Sage Publications, 1996.

Kalu, Ogbu. African Pentecostalism: an introduction. Oxford: Oxford University Press, 2008.

Kalu, Ogbu. "African Pentecostalism in Diaspora." PentecoStudies 9, no. 1 (2010): 9-34.

La Barbera, Maria Catarina. "Identity and Migration: An Introduction." In Identity and Migration in Europe: Multidiciplinary Perspectives, edited by Maria Catarina La Barbera. Cham: Springer International Publishing, 2015.

Levitt, Peggy. "You Know Abraham Really was the First Migrant': Transnational Migration and Religion." International Migration Review 37, no. 3 (2003): 847-873.

Levitt, Peggy and Nina Glick Schiller. "Conceptualizing Simultaneity: A Transnational Social Field Perspective on Society." International Migration Review 38, no. 3 (2004): 1002-1039.

Lundby, Knut. "Patterns of Belonging in Online/Offline Interfaces of Religion." Information, Communication \& Society 14, no. 8 (2011): 1219-1235.

Malmström, Nils. "How do we succeed as a church in Sweden? An African response." Paper presented at the World Alliance for Pentecostal Theological Education (WAPTE) Consultation, Stockholm, Sweden, August 24, 2010.

Marshall-Fratani, Ruth. "Mediating the Global and Local in Nigerian Pentecostalism." In Between Babel and Pentecost. Transnational Pentecostalism in Africa and Latin America, edited by André Corten and Ruth Marshall-Fratani. Bloomington: Indiana University Press, 2001.

McAdams, Dan P. "What Do We Know When We Know a Person?" Journal of Personality 63 (1995): 363-396.

Meyer, Birgit. "Christianity in Africa: From Independent to Pentecostal-Charismatic Churches." Annual Review of Anthropology 33 (2004): 447-474.

Meyer, Birgit and Annelies Moors. Religion, Media, and the Public Sphere. Bloomington: Indiana University Press, 2005.

Robbins, Joel. "The Globalization of Pentecostal and Charismatic Christianity." Annual Review of Anthropology 33 (2004): 117-143.

Robertson, Roland. "Glocalization: Time-Space and Homogeneity-Heterogenity." In Global Modernities, edited by Scott Lash, Roland Robertson, and Mike Featherstone, 25-44. London: Sage, 1995

Shults, F. LeRon and Stephen J. Sandage. Transforming Spirituality: Integrating Theology and Psychology. Grand Rapids: Baker Academic, 2006. 
Seul, Jeffrey R. 1999. “'Ours is the Way of God': Religion, Identity, and Intergroup Conflict." Journal of Peace Research 36, no. 5 (1999).

Ter Haar, Gerrie. Halfway to Paradise. African Christians in Europe. Cardiff: Cardiff Academic Press, 1998.

Ter Haar, Gerrie. "African Christians in Europe: A Mission in Reverse." In Changing Relations between Churches in Europe and Africa: The Internationalization of Christianity and Politics in the 2oth Century, edited by Katharina Kunter and Jens Schjørring, 241-249. Wiesbaden: Harrassowitz Verlag, 2008.

Ukah, Asonzeh F.-K. A New Paradigm of Pentecostal Power: A Study of the Redeemed Christian Church in Nigeria. Trenton: Africa World Press, 2008. 